\title{
Euro-regionalism and struggles over scales of governance: the politics of Ireland's regionalisation approach to Structural Fund allocations 2000-2006
}

\author{
Mark Boyle * \\ Department of Geography, University of Strathclyde, 50 Richmond Street, Glasgow G1 1XN, UK
}

\begin{abstract}
In the context of the publication of Agenda 2000 and the accelerated progress of the Irish economy from 1993, the Republic of Ireland' ${ }^{1}$ position in relation to Structural Fund transfers generally, and qualification for Objective 1 status specifically, has undergone substantial revision since 1997. Against this backdrop, Ireland lodged a formal application with Eurostat in November 1998 to divide the country into two regions, one which would continue to qualify for Objective 1 funds, the other qualifying only for "Objective 1 in transition" status. This "regionalisation" strategy proved to generate substantial controversy both within and between the European Union (EU), the Irish government, and existing regional and local authorities and development agencies. These controversies were rooted in the need to transform the highly centralist scale division of the Irish state. At one level, the purpose of this paper is to evaluate the significance of these conflicts in the light of recent debate in political geography regarding the conditions which serve to ground the EU's broader philosophy of a Europe of the Regions in particular ways, in particular places, at particular times. More generally, however, in respect to both its chosen methodology and findings, the paper hopes to contribute to the development of a process based approach to the contemporary (re)scaling of governance. (C) 2000 Elsevier Science Ltd. All rights reserved.
\end{abstract}

Keywords: Ireland; Agenda 2000; Regionalisation strategy; Scaling of governance; Euro-regionalism; Regional imaginaries

* Tel.: +44-141-548-3762; fax: +44-141-552-7857.

E-mail address: mark.boyle@strath.ac.uk (M. Boyle).

${ }^{1}$ Hereinafter the terms "Ireland" and "Irish" will be used as a shorthand for the Republic of Ireland. 


\section{Introduction}

In July 1997, the Commission of the European Communities (CEC) published Agenda 2000, a blueprint for the future strategic direction of the European Union (EU) (CEC, 1997a,b). To Ireland, a country which has enjoyed considerable success in attracting Structural and Cohesion Funds, this document was the bearer of bad news. With a desire among net contributors to reduce EU transfers and a need to divert resources to those central and eastern European countries hoping to join the Union, it was clear that Ireland could not reasonably hope to benefit from the levels of funding it had secured historically. Moreover, as a result of formidable economic growth since 1993, the country had exceeded the EU threshold required to qualify for full Objective 1 status and was to be labelled an "Objective 1 in transition area", receiving a diminishing amount of resources annually.

Against this backdrop, Ireland lodged a formal application with Eurostat in November 1998 to divide the country into two regions, one which would continue to qualify for Objective 1 funds, the other qualifying only for Objective 1 in transition status. This regionalisation strategy generated substantial controversy both within and between the EU, the Irish government, and existing regional and local authorities and development agencies. These controversies were rooted in the need to transform the highly centralist scale division of the Irish state. The purpose of this paper is to evaluate the significance of these conflicts in the light of recent debate in political geography regarding the role of the EU in changing territorial structures of the state (Keating \& Loughlin, 1996; MacLeod \& Goodwin, 1999; Brenner, 1999). It is written in the belief that a deconstruction of conflicts reveals important insights into the conditions which serve to ground the EU's broader philosophy of a Europe of the Regions in particular ways, in particular places, at particular times. In so doing, the broader aim of the paper, both in terms of its chosen methodology and findings, is to contribute to the recent development of a process based approach to the contemporary (re)scaling of governance.

The paper is structured around five sections. In the first section, a theoretical context for the Irish case study will be elaborated. Second, the scale division of the Irish state will then be explored. Third, Ireland's historical relationship with the EU will be documented, and the manner in which Agenda 2000 altered this relationship, examined. Fourth, using a chronological framework, the main body of the article will then turn towards a detailed exposition of the controversies surrounding the regionalisation strategy. In the final section, an effort will made to tease out those features of Ireland's political system which were most responsible for grounding Agenda 2000, and therein, to reflect upon the wider significance of the case study for future work which seeks to examine the processes lying behind the contemporary construction of the "region" as a key site of governance.

\section{Euro-regionalism and struggles over scales of governance}

Considerable attention has been paid recently to the variety of structures of govern-

ance which are emerging at the urban and regional scales which are serving to play 
an increasing role in the fashioning of the development trajectories of local and regional economies. Amidst the morass of published material which has taken this "institutional turn" in urban and regional political economy as its focus, MacLeod and Goodwin's recent critical intervention stands as a beacon. According to MacLeod and Goodwin (1999), for all its diversity, work in this area is characterised by a key analytic flaw. In so far as the different institutional ensembles which mark different urban and regional economies are accepted as a given, approaches to date have failed to take seriously enough the need to account for the conditions under which structures of governance settle at different spatial scales in the first instance.

In an effort to deepen interest in the processes underpinning the contemporary (re)scaling of urban and regional levels as key sites of governance, MacLeod and Goodwin (1999) advocate greater attention to three factors; the need to outline one's chosen object of enquiry more clearly and therein to shift the epistemological gaze to structures of urban and regional governance themselves; the need to interrogate more fully the relational interplay between economic development, governance and scale; and finally the need to more fully appreciate the role of the wider politics of representation and active processes of political strategizing through which economic development is itself constituted.

Albeit focusing upon specific theories of urban and regional governance, MacLeod and Goodwin's thesis resonates with a number of developments within contemporary political geography (Delaney \& Leitner, 1997). Against the backdrop of a collection of forces which are serving to de-territorialise and re-territorialise state institutions (Brenner, 1998, 1999) Swyengedouw (1997), for instance, has called for a process approach to the understanding of geographical scale, in which the settling down of state functions at different geographical tiers is seen to be a function of social and political struggles occurring at a variety of scales. For Swyengedouw, the tendency to naturalise scales such as the nation, region or the local as obvious sites of governance needs to be resisted. Political space is constructed out of particular historical conditions and normally only after considerable contestation. And whilst these contestations give legitimacy to some scales over others and through time come to reify what Cox (1998a) calls the "scale division of the state", they are always liable to re-ignition.

It is against this backdrop that the phenomenon of the Europe of the Regions should be approached. Since the ratification of the Single European Act in 1987 and Maastricht Treaty in 1993, the EU has pursued a vision of a Europe of the Regions (Nanetti, 1996; Michie \& Fitzgerald, 1997). With the underlying goal of strengthening local and regional democracies and creating better and more sustainable programmes of regional development, the EU has sought to use the lever of the Structural Funds to mobilise regional actors to form a core element in a new structure of multi-level governance. According to Hooghe (1996): 88-89:

"The core of the script since 1989 is known as partnership, a principle and a particular set of organisational structures for collaboration among the European Commission, the state executive, and sub-national authorities. The objective was to empower sub-national authorities in the European arena from member states 
where they are extremely weak, and by specifying how this empowerment should be organised, to achieve a uniform pattern of sub-national involvement. It was an ambitious attempt to transform, in this policy area, the Europe without the regions into a Europe with all regions."

Following MacLeod (1999), the phrase Euro-regionalism will be used herein to refer to this desire on the behalf of the EU to stimulate a growth in regional level governance.

There has been a tendency in many studies seeking to understand the impact of Euro-regionalism to lapse into a descriptive mode in which vague notions such as the hollowing out of the nation state are invoked as a given. The rise of regional governance is simply asserted and insufficient attention is given to the underlying processes of structuration through which the contemporary re-scaling of the state is being constituted. According to MacLeod (1999): 247-248:

"Merely to assert [new regional structures] as an outcome of some ineluctable structural transition to a post-Fordist economy and hollowed out state will tell us little about the political structuration or institutional shaping of any emerging map of Euro-regional governance. To understand the eccentric and uneven contours of the latter, we would be well-advised to explore the determinate social relations and 'politics of place' and 'scale' that serve to activate particular instances of Euro-regionalism."

Moreover, even when foregrounding political contestation, many studies have tended to be somewhat mechanistic. The nuances, emotions, passions, and personalities of political conflicts have tended to be glossed over in favour of somewhat dry and sweeping summaries of their outcomes. This has derived, in part, from the choice of research methods. In-depth qualitative work offering thick description of struggles has tended to be by-passed in favour of somewhat distant third person, factual commentary. Approaching the differential ways in which the Europe of the Regions project embeds itself in different member states through the lens of a process approach to the scaling of governance, then, might require greater use of a research method that can account for the conjunctural, the complex, and the contextual (MacLeod, 1999: 232).

Perhaps the most impressive collection of essays which have examined Euroregionalism within the spirit of the process based approach are those edited by Hooghe (1996). Hooghe (1996: 122) defines his research agenda to comprise a desire to understand how regional "policies are made through a mixture of uneven, unequal, unstable relationships and a compound of co-operative and unilateral strategies." Here, attention has been given to the ways in which institutional outcomes (the nature and extent of regional governance) reflect struggles over visions of governance held by the EU, nation states, and an array of regional and local actors.

In Hooghe's collection, the extent to which the EU has succeeded in invigorating local and regional actors is seen to be complicated by the highly differentiated nature of existing territorial structures of states (Rhodes, 1995; Le Gales, 1998; Benz \& 
Eberlein, 1999). To date, the relative power of different tiers of government to devise regional development plans, negotiate these plans with the Commission, agree final Community Support Frameworks (CSFs) and Operational Programmes (OPs), and implement, monitor, and evaluate plans, has tended to reflect a priori structures (Marks, 1996; Bachtler \& Turok, 1997). This point made, according to Hooghe, it would, nonetheless, be misleading to conclude that Euro-regionalism has made no impact on the institutional fabric of member states.

In his review of the extent to which the architecture of regional governance has been modified in the light of the 1989 to 1993 round of Structural Funds, Marks (1996), for instance, notes a number of new developments. In the more centralised state systems that prevail in both Ireland and Greece, Structural Funds have succeeded in generating calls for greater devolution among sub-national actors. Moreover, in more decentralised states such as Spain and Belgium, Structural Funds have fed into deeper processes of regional devolution rooted in ethno-cultural conflicts, and thus have served to consolidate a regionalisation of state functions. In France, Germany, and the UK meanwhile, whilst the rigid institutionalisation of existing national-regional relations has made these structures generally impervious to influence, space has been created for some regional actors to play an increased role.

Through an exploration of a series of struggles which surrounded the latest phase in the grounding of Euro-regionalism in Ireland, this paper intends to contribute to the development of a richer application of a process based approach to the scaling of governance in this context (see also Baeten, Swyngedouw \& Albrechts, 1999; MacLeod, 1999). In choosing a methodology which seeks to explore the detailed contours of political contestation, and in telling the story in a way which captures the messiness of conflicts on the ground, the intention is to contribute towards an understanding of "the social, economic, political, and ideological forces that appear to be constituting specific scales such as the 'region', and multi-scalar matrices such as Euro-regionalism, as the hegemonic scalar fixes of late capitalism" (MacLeod, 1999: 248).

\section{Euro-regionalism and the scale division of the Irish state}

The scale division of the Irish state sets a vital context within which to understand the Irish engagement with Euro-regionalism. The Irish state is comprised of two tiers, central and local, and as such, is one of the few states in Europe to lack any meaningful form of regional government. Moreover, central government dominates public life and local government is extremely weak. A British inheritance from 1898 legislation, local government rests at the County level (Fig. 2), and is comprised of a series of County Councils and County Boroughs. Until 1999, these bodies lacked any constitutional status. Historically, they have been allowed a limited range of competencies and have been subjected to strict ultra-vires regulation (McCafferty \& Walsh, 1999). Furthermore, Ireland is somewhat unique in that local administrators rather than local politicians exert greatest power at the local level with the County manager being perhaps the most powerful player. Under 5\% of GDP and only around $12 \%$ of public expenditure is discharged through local government (Laffan, 1996). 
Whilst lacking a formal regional tier of government, it would be misleading to infer that the regional scale is bereft of any institutions. Three types of regional actors can be identified; regional arms of national organisations, Europe inspired regional authorities, and regional development agencies. In the first instance, a variety of national agencies have organised themselves on a regional basis. These include the Irish Development Agency (IDA) and the various regional Health Boards. Controlled by strong centralist administrations, these regional bodies lack any meaningful decision making powers and represent little more than delivery mechanisms for national programmes.

Secondly, Eurostat, up to 1999 at least, has viewed Ireland in its entirety as a NUTS II region. ${ }^{2}$ As a direct consequence of pressure from the EU in the 19941999 round of Structural Fund allocations, Ireland, nevertheless, established eight new regional authorities which were ascribed NUTS III status (Fig. 1). These authorities were controlled by committees drawn from politicians involved in local government. To date, regional authorities have had relatively little power. With a tiny staff contingent and no budget, their main role has been to monitor the ways in which Structural Funds have been spent. Although based upon an amalgamation of existing County boundaries, the geographical parameters of these authorities are somewhat artificial and they have lacked widespread public recognition and support.

Finally, Ireland also has number of regional development organisations with remits to develop geographically discrete areas (Callanan, 1999). These include Shannon Free Airport Development Company (SFADCo), Údarás na Gaeltachts, and more recently and importantly in the present context, the Council for the West and its institutional offshoot the Western Development Commission. The Council for the West was established in the early 1990s. Dubbed the "Bishops Initiative", it grew first as a lobby group concerned with the erosion of the social, economic, and cultural base of the west of the country. With the support of the then Taoiseach Albert Reynolds, T.D. for the North-Western seat of Longford-Roscommon (Fig. 2), the Council grew to include a wider constituency of social and economic partners. In response to the Council's publication of a Challenge Document, the Irish Government formally established the Western Development Commission in 1997, and placed it into legislative stature in February 1999. Covering a total of seven counties in the North-West of Ireland (Fig. 2), the Western Development Commission has powers to make loans for economic development from a IR£25 million Investment Fund (Western Development Commission, 1999).

Ireland then, is best characterised in terms of a strong centralist political culture, a weak system of local government, and a somewhat ad hoc patchwork quilt of relatively weak regional actors. From this brief sketch, it is useful to draw attention to three aspects of the scale division of the Irish state that have proven key in shaping its engagement with Euro-regionalism; the national scale dependencies of local and

2 The acronym NUTS is derived from Nomenclature of Territorial Statistical Units, and refers to the geographical scales which Eurostat uses for statistical purposes. Until 2000 Ireland was recognised by the EU as a NUTS II level in its entirety. 


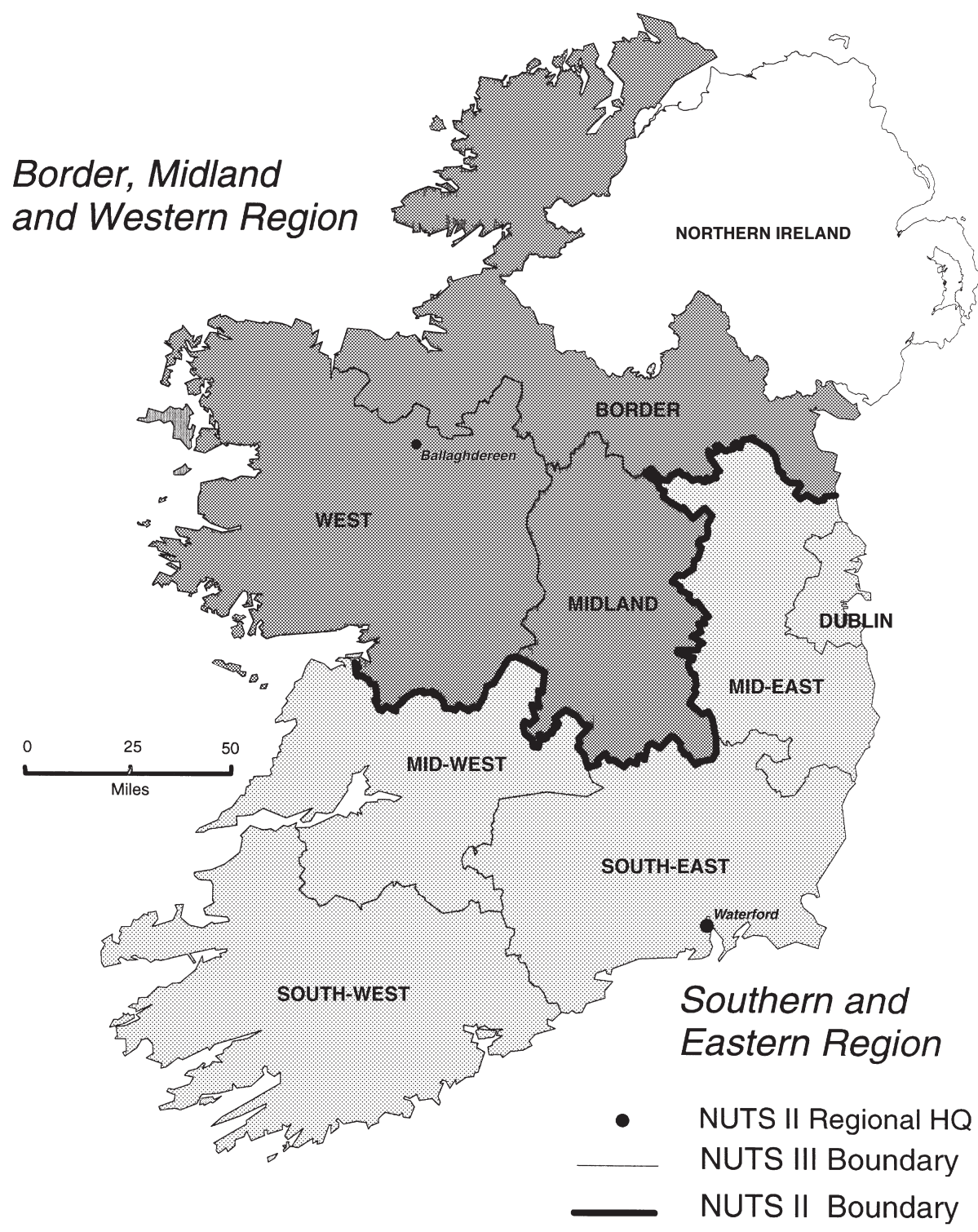

Fig. 1. NUTS II and NUTS III Regional Authority areas.

regional state actors, the limited development of a regional imaginary, and the delocalisation of local interests. First, constructed as a centralist regime, sub-national arms of the Irish state are characterised by their limited degree of local dependency. The concept of local dependency, first coined by Cox and Mair (1988), refers to the dependencies of various state and non-state actors on the reproduction of certain 


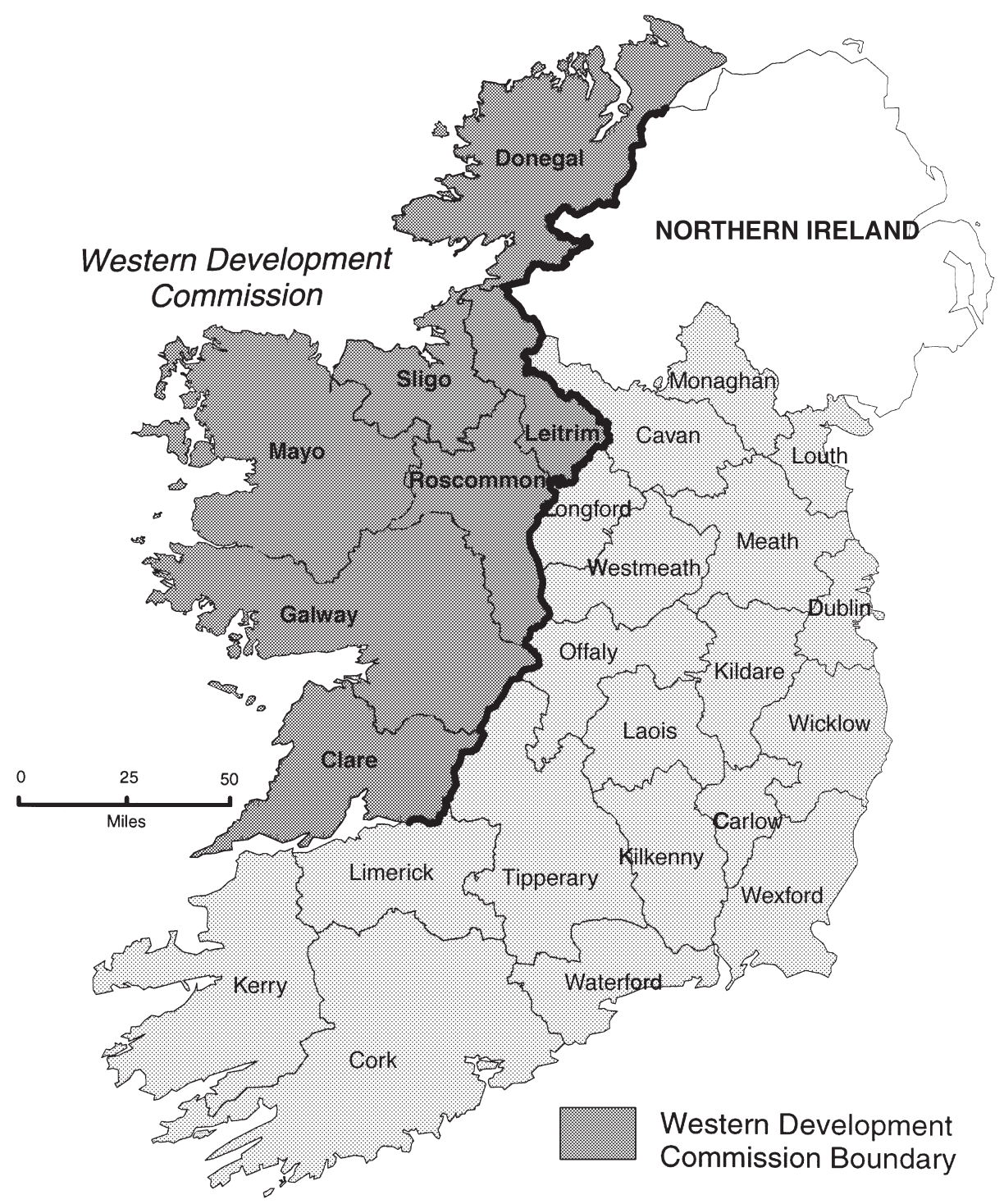

Fig. 2. County boundaries and area of responsibility of the Western Development Commission.

social relations within a prescribed territory. Financed and controlled from Dublin, both local government and the various regional actors identified above lack strong dependencies on sub-national spaces for their own existence. As such, the material bases for these actors to spearhead local and regional development trajectories is limited.

Second, both MacLeod (1999) and MacLeod and Goodwin (1999) point to the critical importance of the politics of representation in the grounding of Euro- 
regionalism in specific localities. Here, distinctive regional identities or regional imaginaries prove to be a vital precursor to the erection of an institutional ensemble at the regional scale. These identities animate regional armatures to map and give meaning to the national space in ways which naturalise the belief that these spaces therein require distinctive forms of state intervention. In part a result of the existing scale division of the state, it is clear that Ireland is marked by an absence of regional imaginaries. To be sure the ancient Provinces of Ulster, Munster, Connacht and Leinester do continue to have meaning for some people but they have no contemporary administrative relevance. The existing patchwork quilt of regional agencies are marked by the way they cut across one another and map onto national space only weakly. As Laffan (1996): 322, notes:

"The counties provide a critical focus for collective identity within Ireland, although their importance as an arena of identity owes more to Gaelic games than to vibrant local politics... Powerful local identities are matched by a strong sense of national identity, which leaves little room for intermediate identities. The unifying nature of Irish nationalist mobilisation meant that little popular sentiment was attached to the ancient provinces."

Bereft of strong regional identities, it is unsurprising that the scale division of the Irish state has failed to give serious contemplation to the erection of a regional architecture.

Finally, Ireland is marked by a de-localisation of local and regional interests, as local and regional lobby groups channel their activities directly through the national political system. In the United States context, Cox (1998b) has called for more attention to be paid to these de-localisation tendencies. Here, actors with strong local and regional scale dependencies attempt to colonise central branches of the state and harness the powers of State and Federal governments. Perhaps because of the relative weakness of the central state in the United States, national government is constantly vulnerable to cannibalisation by local interests. Unlike typical parliamentary systems therefore, where party allegiance is strong and representation of a strictly territorial nature marginalised, the emphasis is on the "strength of the relation between the legislator and his/her constituency as opposed to that existing between legislator and Party" (Cox, 1998b: 3).

With a strong central government of the classic parliamentary form, one might anticipate that Ireland would be the last state in which turf politics triumphed over party allegiance. Such a conclusion would be erroneous. The structure of the Irish state is one that facilitates the expression of local interests through respective Irish parliamentarians (Sinnott, 1986). Whilst it would be misleading to downplay the significance of strong central parties, it is nevertheless true to say that:

"Irish parliamentarians (T.D.s) are almost all natives of the areas they represent and a very high portion of them $(60 \%)$ continue to serve on their local councils while in the Dáil. Irish parliamentary representatives engage in extensive constituency work, acting as brokers between their constituencies and the state. A local 
political base and a record of service to the locality is vital for electoral success. Localism and brokerage are prevalent not just because of Ireland's size and culture, but because the state tradition is so centralised. T.D.s act as intermediaries between their constituents and a remote state in Dublin." (Laffan, 1996: 321)

\section{Agenda 2000: a new context for Ireland}

It is against the backdrop of this scale division of the state that Ireland's engagement with EU Structural Funds in general, and Agenda 2000 in particular, needs to be understood. Ireland joined the EU in 1973 as one of the poorest member states, with a GDP per capita of $62 \%$ of the EU average (McAleese \& Mathews, 1987). Despite economic growth, in both the 1988 and 1994 round of Structural Fund allocations, it qualified for full Objective 1 status, a classification reserved for those areas with a GDP per capita of less than $75 \%$ of the EU average (Walsh, 1995). As one of Europe's most underdeveloped countries (Peillon, 1994), Ireland has emerged as a substantial net recipient of Structural Fund transfers (Murray, Greer \& Walsh, 1995). Between 1988 and 1999, it received the largest per capita transfers of any EU country (Laffan, 1999: 12). Further, in 1992, along with Spain, Greece and Portugal, it also began to benefit from the new Cohesion Fund.

Ireland's embrace of this new treasure chest did not involve any new institutional innovation; "adaptation to the demands of EU membership did not entail major changes in Ireland's administrative culture or its system of public policy. Servicing the Brussels machine was grafted onto the existing machinery of government" (Laffan \& O'Donnell, 1998: 169). Given the highly centralist scale division of the state, it has been central government and in particular the Department of Finance that has played the key role in the formulation and negotiation of the two National Development Plans which constituted the country's Community Support Frameworks in the 1988-1993 and 1994-1999 rounds of funds (O'Donnell \& Walsh, 1995). The aims of the Department of Finance have simply been to maximise the take of funds and then, on a national bases, plan for their disbursement.

In July 1997, the European Commission published Agenda 2000, the Commission's blueprint for the future strategic direction of the European Union (CEC, 1997a,b). Informing the document were two important factors. First, financial provisions had to be made regarding requests for accession from a number of central and eastern European states. It was recommended that beyond current discussions with Cyprus and Malta, accession negotiations should be opened with Hungary, Poland, the Czech Republic, Slovenia and Estonia, with a view to incorporation by 2005 (Andrews, 1998). Second, the financial framework was influenced by vigorous calls among substantial net contributors (especially Germany) to reduce their contributions (Bachtler, 1998).

For Ireland, the likely financial retrenchment arising from these two factors was compounded by its remarkably successful rate of economic growth since 1993. Whilst per capita GDP stood at around IR£7500 in 1992, by 1997 it had reached 
over IR£11,000 (Laffan, 1999). During this period, annual growth rates of up to $9 \%$ earned the country the title Celtic Tiger. A consequence of this rapid economic growth was that Ireland quickly changed from being a relatively poor nation to one whose income now came close to the European average (O'Leary, 1997, 1999). In the years 1994-1996, for instance, Eurostat estimated the country's GDP per capita to be $88 \%, 92 \%$, and $98 \%$ of the EU average, respectively (Border Regional Authority, 1998a). The problem this presented was that against the likely backdrop of an already diminished budget, Ireland had now breached the ceiling of $75 \%$ of the EU average GDP per capita set for regions to qualify for full Objective 1 status. $^{3}$

By 1998, it had become apparent to the Irish government that perhaps the existing network of eight NUTS III regional authorities could be used to maximise Structural Fund allocations for the period 2000-2006. It was clear that whilst the entire country would breach the $75 \%$ threshold, at least three NUTS III regions, Border, Midlands and West (referred to as the BMW group) had GDP per capitas beneath this level (O’Leary, 1999) (Table 1). Perhaps one way to rescue Ireland from the worst excesses of Agenda 2000 would be for the country to adopt a regionalisation strategy, in which it would be divided into two new NUTS II regions; the BMW group qualifying for Objective 1 status, and the remainder being subsumed into an Objective 1 in transition area (Fig. 1). It was against this context that struggles over scales of governance began.

\section{Social struggles and the scaling of governance: debates in Ireland over the regionalisation strategy}

Vigorous debate over Ireland's strategy towards the next round of Structural Fund allocations began in Spring 1998 and continued until final resolution to Agenda 2000

${ }^{3}$ Among the more important details of Agenda 2000 which affected Ireland were the following:

1. EU Budget 2000-2006 - to be maintained at $1.27 \%$ of EU GNP with the Structural Fund budget limited to a ceiling of $0.45 \%$ of EU GNP.

2. Structural Funds - 275 billion ECU (1997 prices) to be available between 2000-2006. 45 billion ECU to go to accession states, 210 billion ECU to be spent on existing member states and 20 billion ECU to be available through the Cohesion Fund. No country to receive monies exceeding $4 \%$ of their GNP.

3. Structural Fund Objectives - 7 Objectives previously used for targeting funds were to be reduced to 3. Objective 1 funds to be targeted towards the most lagging regions. Objective 1 and 2 regions to be reduced from $51 \%$ to $35-40 \%$ of EU's population. Threshold for Objective 1 would be strictly applied at $75 \%$ of EU GDP per capita. Eurostat, the "independent" statistical agency would make final decisions on eligibility. Eligibility for Objective 1 would be based upon average GDP figures for the period 1994-1996. Regions losing Objective 1 status were to be given Objective 1 in transition status. Support for transition areas would be gradually reduced to nil by the end of 2006.

4. Cohesion Fund - Fund still available to nations with GNP per capita figures less than $90 \%$ of the EU average, subject to mid term review (2003).

5. Community Initiatives - number of Community Initiatives would be reduced from 13 to 5 , and from 9\% to $5 \%$ of the budget. Inter-Reg and Leader would be maintained and a new Equal initiative would be established (CEC (1997a,b) and Border Regional Authority (1998a)). 
Table 1

Economic performance of the Irish regions 1991-1995

\begin{tabular}{|c|c|c|c|c|c|}
\hline \multirow[t]{2}{*}{ Region } & \multicolumn{3}{|c|}{ GDP per capita IR£ per person } & \multicolumn{2}{|c|}{$\begin{array}{l}\text { GDP per capita as a } \% \text { of EU } \\
\text { average }\end{array}$} \\
\hline & 1991 & 1995 & Change $\%$ & 1994 & 1995 \\
\hline Border & 5909 & 7666 & 29.7 & 71.6 & 71.1 \\
\hline Midlands & 5416 & 7125 & 32.9 & 63.5 & 66.1 \\
\hline West & 5389 & 6943 & 28.8 & 60.6 & 64.4 \\
\hline $\begin{array}{l}\text { Dublin and } \\
\text { Mid-East }\end{array}$ & 8430 & 12007 & 42.4 & 105.6 & 111.3 \\
\hline South-West & 7519 & 10537 & 40.1 & 90.9 & 97.7 \\
\hline Mid-West & 6712 & 9386 & 39.8 & 85.6 & 87.0 \\
\hline South-East & 6452 & 8575 & 32.9 & 79.2 & 79.5 \\
\hline State & 7169 & 9925 & 38.4 & 88 & 92 \\
\hline
\end{tabular}

a Source: compiled from O’Leary (1998): Table 1, and Border Regional Authority (1998a: 28).

was reached at the Berlin Summit in late March 1999. A wide variety of sources of information were marshalled to shed light on the events of this particular period. As impressed above, adopting a process based approach to the scaling of governance carries with it certain methodological obligations. As MacLeod (1999: 231), observes, it calls for an added sensitivity towards the "politics of place", and "the contingent and the contextual, when analysing the re-composition and re-scaling of European urban and regional governance". To gain insight into processes requires insertion into the muddle that often surrounds public debates. In-depth qualitative research methods are of critical importance.

To this end, the account presented below draws upon three principle sources of information. First, every copy of The Irish Times, Irish Independent, and Ireland Today published between March 5th 1998 and September 30th 1999 was reviewed, and further information from local newspapers sourced where relevant. ${ }^{4}$ Second, copies were obtained of all debates held in the Houses of the Oireachtas on the regionalisation strategy specifically, and Agenda 2000 discussions more generally, between January 1st 1998 and September 30th 1999. This material covered all relevant debates held in the Dáil (lower house) and Seanad (upper house) and associated speeches and press releases, and all relevant Parliamentary Committee Meetings. ${ }^{5}$

\footnotetext{
${ }^{4}$ Both The Irish Times and Irish Independent are leading daily newspapers and publish same day editions on the WWW (www.ireland.com/ and www.independent.ie/). The Irish Times carries a special section on European issues - Euro Times - which gives excellent coverage of debates across the EU. Ireland Today is a daily newspaper on the WWW (www.ireland-today.ie/) and is largely designed for migrants in the Irish diaspora. A range of local and regional newspapers are also published on the WWW (www.niceone.com/newspap.htm).

${ }^{5}$ Full transcriptions of Dáil and Seanad debates, minutes from Parliamentary Committees, and details of press releases from the Taoiseach's Office are published on the official Irish Government WWW page (www.irlgov.ie/).
} 
Finally, a total of 13 semi-structured interviews were held between May and July 1999 with a number of key actors in the sphere of regional and local development. ${ }^{6}$

In the sections to follow, I aim to use material collected from these three sources to reconstruct the key debates which took place over the regionalisation strategy. Employing a chronological framework in order to remain faithful to the way in which debates unfolded on the ground, discussion is structured around six major themes; the role of Agenda 2000 in the mobilisation of existing "regional armatures", the arguments pursued in the Dáil and Seanad against the regionalisation strategy during the "summer of discontent", concern over the extent of regional devolution in Ireland, the government's announcement that it was to pursue regionalisation, the role of political corruption in the mediation of negotiations, and the period of negotiation and compromise leading to the final deal struck in Berlin.

\section{Agenda 2000 and the mobilisation of regional armatures}

The possibility that Ireland might adopt a regionalisation strategy in a bid to avert the worse excesses of Agenda 2000 proved a stimulant to those regional armatures most likely to benefit — the Border, Midlands, and West (BMW) regional authorities and the Western Council and Western Development Commission. Regional bodies were used by a range of representatives from the private sector (for instance, Chambers of Commerce, farmers associations, environmental consultants, and utility companies), voluntary organisations (for example women's networks and anti-poverty groups), branches of the local state (for instance, County Councils, Health Boards, and County Enterprise Boards), and a range of other public bodies (such as Universities, FÁS, and Forbairt), as a vehicle through which contributions to the next National Development Plan might be made. However trivial, the growth of these new relationships suggested that the regional bodies were at last beginning to thread into and form part of emerging regional "social blocks".

On February 6th 1998, the Minister of Finance invited Ireland's eight NUTS III regional authorities to make submissions by the end of June 1998 for the next National Development Plan. Despite their artificial creation and relative lack of power, the BMW authorities spearheaded calls from a range of constituencies for the regionalisation strategy to be implemented. Beyond the fact that they had not benefited as much as other regions from the rise of the Celtic Tiger, a wide range additional arguments were used in the BMW submissions in support of their claims

\footnotetext{
${ }^{6}$ Interviews were conducted with two NUTS III regional authorities (one in (Midlands) and one outside (Mid West) the proposed Objective 1 area), the two main regional development agencies in Ireland (again one in (Western Development Commission) and one lying beyond (Shannon) the proposed Objective 1 area), and representatives from nine County Enterprise Boards (at least one from each of the eight NUTS III regions - Waterford, South Cork, Limerick City, Galway, Clare, Offaly, Sligo, Dublin City, and West-Meath). A total of 35 County Enterprise Boards were established in Ireland under the Operational Programme "Local Urban and Rural Development" in the 1994-1999 CSF. Their function is to promote the establishment and growth of small companies in their areas. The interviews proved useful in clarifying the detail of particular debates, including the movers and shakers behind agendas and the relative weight to be given to different viewpoints.
} 
for Objective 1 recognition. The Border Regional Authority (1998a,b) for instance, pointed to economic retardation caused by the political and civil strife of being adjacent to Northern Ireland, the fact that it was in the front line in the peace process, and that it now had to deal with the new competitive threats of Economic and Monetary Union without the UK. Midland Regional Authority (1998) pointed to the continued over-reliance on agriculture in the region, its weakly developed urban fabric, infrastructure and telecommunications base, and its relative backwardness as a tourist attraction. Finally, the West Regional Authority (1998) cited as its major difficulties the region's rural based economy and dependency upon a declining agricultural sector, its generally poor infrastructure, the problems caused by population decline and out-migration, and the social and economic imbalances which exist between Galway city and its rural hinterland.

The existence of the Council for the West alongside the Western Development Commission also ensured a powerful lobby group for western counties inside the proposed Objective 1 area. Lying outside government, the Council for the West was more polemical in its demands. Lying inside the Irish state structure, the Western Development Commission needed to be more guarded but nevertheless exercised better channels of access to key decision makers in Dublin. Marian Harkin, Chairperson of the Council for the West, emerged as one of the most vigorous public advocates of regionalisation, whilst Liam Scollan, Chief Executive of the Western Development Commission, also made repeated calls for the retention of Objective 1 status (Western Development Commission, 1999).

Alert to the fact that the EU would insist that any division of the country must be accompanied by a greater role for regional authorities, these various regional armatures also used the context set by Agenda 2000 to push for more power to be devolved from Dublin. Crucially however, there were no serious calls for the erection of substantial new regional authorities with wide ranging powers and enjoying the privilege of suffrage. Instead, calls for devolution amounted to little more than the introduction of spatial as opposed to national/sectoral planning and an enhanced role for the regions in the preparation of regional plans. This observation is consistent with the findings of Coyle and Sinnott (1992) which likewise point to the limited ambitions of regional actors.

Arguably, Midland Regional Authority (1998) presented the most sophisticated critique of regional devolution in Ireland. It begun its submission to the National Development Plan by criticising the role the regional authorities had been asked to play to date as placing them in a "helpless position as regards having any ongoing influence" (Midland Regional Authority, 1998: 81). Whilst an improvement, the recent decision to allow regional authorities to sit on the overall Community Support Framework monitoring committee and the monitoring committees of all Operational Programmes was not enough. Midland Regional Authority offered four further recommendations which would empower the regional tier with greater teeth:

1. Once data for the national plan had been collected, a process of integrating sectoral and regional submissions should be commenced. This would result in a number of coherent, identifiable packages of expenditure at regional level; 
2. Provision should be made for the integrated monitoring of these packages through careful data collection at the regional level and the establishment of a monitoring evaluation group;

3. A technical officer should be appointed within each region with responsibility for the co-ordination of these expenditure programmes and their monitoring;

4. At national level, a CSF monitoring sub-committee should be established to monitor the development of regionally prescribed Operational Programmes.

In other words, the vision of the Midland Regional Authority was that of grounding national sectoral programmes more within a regional framework and giving an enhanced role to the regional authorities to design and monitor these area based packages.

Whilst animated by the context created by Agenda 2000 and the possibility that Ireland might pursue a regionalisation strategy, it would be incorrect to presume that regional armatures in the proposed Objective 1 area were in themselves ever likely to be powerful enough to bring about change. As noted above, power in Ireland lies primarily in the Houses of the Oireachtas. It is towards controversies played out in both the Dáil and the Seanad that attention now turns.

\section{The summer of discontent}

The regionalisation debate first announced its arrival in Dáil Éireann on April 29th 1998. In a guarded statement on the government's position, Minister for Finance Charles McCreevy argued:

"I have never given the definitive line the government is likely to pursue because it has not yet decided on its strategy... the government's objective in this round of Structural Funds will be to secure for Ireland the optimum level of funding. If that means going down the route of sub-regionalisation, subject to the Commission's agreement, then that is the route the government will go." (C. McCreevy, T.D. for Kildare North, Minister for Finance, Fianna Fáil, Dáil Debates, 29/4/98)

Crucially then, and from the outset, it was clear that for the government, regionalisation would be approached first and foremost as an exercise in subsidy shopping.

The strategy of regionalisation was the subject of further motions which were comprehensively debated in the Dáil on June 11th and November 11th 1998, and the Seanad on May 27th, June 3rd, and October 15th 1998. A key feature of these debates was the manner in which politicians lined up on territorial rather than party political lines. With some exceptions, it was those T.D.s and Senators from the proposed Objective 1 in transition area who emerged as principal opponents of the regionalisation strategy. While the Labour Party appeared to have a united position on regionalisation - they sought to reject it — this again reflected the fact that the party's support base was rooted in the working class neighbourhoods of Dublin, Cork and Limerick, cities which lay outside the BMW region. Regionalisation proved 
to emphasise a form of turf politics, where defence of one's geographical constituency became more important than adhering to a party line. Whilst in the end strong centralised party controls triumphed, for some time, a cross-party territorial bloc of T.D.s in the Objective 1 in transition region exerted considerable pressure on the government.

The principal concern among T.D.s and Senators who were opposed to the regionalisation strategy was that it would lead to substantial reductions in funds for Objective 1 in transition areas. This was despite government assurances that: "if a part of the country were to qualify for Objective 1 as a result of the proposed reclassification, this would not mean the rest of the country would be treated any less favourably than it would have been anyway under the transition regime currently proposed for Ireland as a single region" (C. McCreevy, Dáil Debates, 10/11/98). The belief that the division of the country would have detrimental effects on the most populous Southern and Eastern regions nevertheless remained pervasive throughout the summer of 1998. Its persistence was to lead commentators from BMW constituencies to wonder aloud as to why it continued to be in circulation and whose interests it was serving:

"Because of their misunderstanding of the question or a narrow vested political interest, some commentators have muddied waters and made the debate baffling to many citizens... Some Deputies may misunderstand the regionalisation proposal and genuinely fear their region or the disadvantaged sections of society in general will lose out. I share that concern but believe the fear is a groundless one in this instance. Others may understand the regionalisation proposal quite well but may not be above using a bit of scaremongering for short-term electoral advantage." (C. O'Caolain, T.D. for Cavan Monaghan, Sinn Féin, Dáil Debates, $10 / 11 / 98)$

In their efforts to avoid what they perceived would be significant reductions in EU transfers to their areas, opponents of regionalisation made use of three principal debating strategies. In each case, as the debates evolved, the government developed three equally strong lines of response. First, some called for the government to attempt to secure Objective 1 status again for the whole country, using Ireland's GNP/GDP ratio as a basis for pleading a special case. This case was to be buttressed by the observation that transport costs are greater for Ireland since it is the only island economy in the EU, and that Ireland suffers from severe infrastructural backwardness.

Ireland's GNP is substantially lower than its GDP due to its disproportionate reliance on multi-national enterprises. As a result of significant repatriation of profits, some commentators believed that the decision to award Objective 1 status on the basis of GDP was unfair (O'Leary, 1998, 1999). This line of argument, however, was dismissed by the government as unlikely to meet with sympathy from fellow European negotiators. Further, while it might draw regions other than the BMW group beneath the Objective 1 threshold, the country as a whole would still breach the guidelines: 
"The fact of the matter is that the indicator chosen for Objective 1 status must be one that commands support and acceptance across the European Union. GDP per-capita meets this requirement and in the negotiations to date there has be no pressure by any member state to open up this issue... In any event, Ireland's per capita GNP, expressed as a percentage of the EU average, has been over $75 \%$ for several years now." (C. McCreevy, Dáil Debates, 10/11/98)

Secondly, some opponents suggested that while their region as a whole could not qualify for Objective 1 status, "blackspots" at a more micro scale could and therefore deserved to be included as part of a more complex map. This theme was unsurprisingly championed to the greatest degree by the Labour Party whose support base derives from these blackspots. The result of the regionalisation strategy otherwise would be "a dividing of the country and the setting of the disadvantaged rural dweller against his [sic] urban equivalent" (Senator J. Costello, Labour Party, Seanad Debates, 15/10/98). In a stout defence of the impossibility of this strategy, the government again dismissed it as worthy of serious consideration:

"Any new NUTS II level — the reference regime for Objective 1 status — must be generally in line, as regards population and size, with the norm across the EU. Its components must also be geographically contiguous. This means that the option of designating micro-regions, such as poverty blackspots within regions and cities, to avail of Objective 1 funding for those particular areas is not available. In any case, if it were possible to direct Objective 1 assistance to relatively poor urban micro-regions, very wealthy areas of the community, such as the cities of London, Paris, or Hamburg, would be able to seek Objective 1 status for their urban blackspots. This would dissipate the overall allocations for Objective 1 assistance, and reduce the amount available for Ireland." (C. McCreevy, Dáil Debates, 10/11/98)

Finally, some opponents warned that if Southern and Eastern regions were excluded, then domestic funds would have to flow into them to offset losses. This kind of pleading brought promises of funding from the government, with the general proviso that exchequer transfers be in line with the broader goals of national economic development. Further, it allowed the government to distract attention away from the importance of the regional distribution of EU transfers, by focusing instead on the entire spending package available through the next National Development Plan. T.D.s and Senators from Southern and Eastern regions could be satisfied that even if regionalisation went ahead, their regions would not lose out overall:

"As long as we continue with the prudent policies which have played a major part in securing the economic growth of recent years, we should have the resources to make good the reduction in EU aid for the country as a whole." (C. McCreevy, Dáil Debates, 10/11/98)

By the end of the summer of 1998, therefore, while not declaring its hand, the government had began formulating defences of the regionalisation strategy against 
each of the lines of contention advanced by its opponents. Frustrated by their lack of progress, some opponents attempted to take matters into their own hands. As late as November 1998, Labour T.D. for Dublin North West, P. De Rossa was reported in The Irish Times (10/11/98) as having asked the Department of Finance, under the Freedom of Information Act, for copies of official records concerning the relative advantages or disadvantages of the two regions strategy. Bitter about the government's failure to countenance serious debate, he is quoted as saying: "The Department listed 10 documents or papers that had been produced on this issue but my application was refused on the grounds that "public disclosure would be contrary to the public interest', and would also 'risk adversely the international relations of the state in so far as the EU is concerned"'.?

\section{Concern over regional devolution}

Given Ireland's history of over centralisation and the stranglehold that the Department of Finance has had on EU funding, both proponents and opponents of regionalisation persisted in reminding the government about the EU's attachment of conditions in the disbursement of Structural Funds. A key debate was initiated on the assumption that; "Given their present make-up, the regional authorities are inadequate... Does the government have the will to devise an effective sub-regional scheme that will be empowered to draw down objective one status?" (Senator P. Burke, Fine Gael, Seanad debates, 27/5/98). For proponents of regionalisation, the fear was that their case might be undermined if genuine regional administrations were not put in place. For opponents, the concern was that Ireland might antagonise the European Union by appearing to be dividing the country merely to "subsidy shop", and thereby threaten overall transfers. The following quote, offered by an opponent of regionalisation, exemplifies such concerns:

"If one is not going to allow any form of serious devolution of power to the regions, there is no way one can hope to persuade Brussels to recognise our regions.... Eurocrats, in spite of all their limitations, operate according to a certain logic. If regions are alleged to exist, Brussels wants them identified, defined in law, and given independent powers to make decisions about themselves.... Given that the Department of Finance has such an obsession with controlling the expenditure of every other government department, how will it allow a regional authority in the deprived parts of Connacht or Munster to have the sort of autonomy Brussels would expect? I am quite convinced that the Department would happily forgo Objective 1 status rather than concede to direct regional negotiations with Brussels as such negotiations would take the power out of the Department's hands." (Senator B. Ryan, Labour, Seanad Debates 3/6/98)

The extent to which the success of the application to regionalise the country would

\footnotetext{
7 The Irish Times, “Government responds to regionalisation claims" 10/11/98.
} 
depend upon the creation of new regional structures was pressed home further in an interview published in The Irish Times (16/9/98) with EU Commissioner for Regional Affairs, Monika Wulf-Mathies. In this interview, Wulf-Mathies was asked what she thought of the regionalisation debate raging in Ireland. She observed:

"I can well understand how people are trying to defend current levels of financial support. It would be a nice idea if more funding was to be forthcoming this way, to organise the country like that. But I think this would only be possible, and this has always been the position of the Commission, if it went hand in hand with changes in political and decision making structures in the regions - with devolution taking place not only to get better structural funding, but as a real change in the legislative and regional make up of the country. So far I see interest in getting as much money as possible, but don't yet see this corresponding with changes in regional governance." 8

The force of this argument led the government to eventually concede that:

"In the event of a regionalisation approach being adopted, the regional administrative framework may require adjustment. Such adjustment as is necessary will be the subject of discussion with the Commission and will take account of the views of the regional interests. A major consideration in this general regard is that the efficient and effective administration and management of Structural Funds spending, for which Ireland enjoys a just reputation, must not be jeopardised, particularly in the coming period of declining overall assistance from Europe. Notwithstanding this, the government would, I believe, be prepared to give any new regional structures a real role in the preparation, management, and monitoring of the regional components of the National Development Plan." (C. McCreevy, Dáil Debates, 10/11/98)

Despite official sentiments like these, many commentators remained unconvinced. The results of an "Expert Survey" of the policy positions of Ireland's main political parties in 1997, for instance, testifies to a widespread belief among informed commentators that not only was decentralistion of government functions a low priority, but that in any event, there was a deep seated reluctance to countenance substantial devolution per se (Laver, 1998).

\section{The decision to adopt a regionalisation approach}

On November 17th 1998, Irish Taoiseach Bertie Ahern issued a press release finally confirming that the Government had "decided today to pursue an application to Eurostat... for a change from Ireland's current status as a single region to one

\footnotetext{
8 The Irish Times, "The problems of division" 16/9/98.
} 
comprising two regions". ${ }^{9}$ Employing their essential barometer of maximising EU transfers, the government it seemed, had finally accepted that regionalisation was the optimum strategy to adopt. Contained in the Taoiseach's press release, nevertheless, were two additional points which were to generate further controversy.

First, as expected, Objective 1 status was proposed for the BMW region, but in addition, two further Counties were added; Clare and Kerry. Although having GDP per capita figures above $75 \%$ of the EU average (in 1995, Clare, 88\%; Kerry, 102\%), when connected to the BMW group, the overall average remained less than the critical threshold for Objective 1 status. According to the government:

"The inclusion of Clare and Kerry in the regional authority area of the West, which was under consideration from the outset of the examination of regionalisation and was mooted in documents circulated to Departments during the summer, will ensure that the new Objective 1 region will encompass the western seaboard from Donegal to Kerry, an area on the very periphery of the European Union." 10

The decision to include Clare and Kerry raised a political storm. Many commentators believed that the government had been coerced by the activities of Independent T.D. for Kerry South Jackie Healy-Rae. According to Ireland Today (19/11/98), support by Healy-Rae for the weak coalition government (Table 2) was so vital that he could exert power; "the inclusion of Kerry smacks of what is known as "stroke politics". Many people, rightly or wrongly, believe that Deputy Jackie Healy-Rae, Independent from South Kerry, made the inclusion of Kerry in the "poorer" region a condition of his continued support for the minority government." the need for regions to be geographically coterminous, Clare then also had to be

Table 2

Status of parties making up the 28th Dáil at November 17th $1999^{\text {a }}$

\begin{tabular}{lc}
\hline Party & No. of T.D.s \\
\hline Fianna Fáil & 76 \\
Fine Gael & 54 \\
Labour & 21 \\
Progressive Democrats & 4 \\
Green Alliance & 2 \\
Socialist Party & 1 \\
Sinn Féin & 1 \\
Independents/others & 7 \\
Total & 166 \\
\hline
\end{tabular}

\footnotetext{
a Fianna Fáil and Progressive Democrats rule as a weak coalition government. Four additional votes from other parties or Independent T.D.s are needed to carry a vote. Source: WWW.irlgov.ie/
}

\footnotetext{
9 Press release, Taoiseach's Office, "Regionalisation” 17/11/98.

10 ibid.

11 Ireland Today, "National interest versus local interest", 19/11/98.
} 
included to make Kerry's inclusion "look" logical (Fig. 2). The precarious arithmetic of Dáil Éireann, it seemed, was driving the proposal.

Other Independent T.D.s who supported the government were now reputed to be reconsidering their position. According to Ireland Today (24/11/98):

"The news this morning that Independent Deputy for Wicklow, Mildred Fox, is considering withdrawing her support is a lesson for the government that if you give to one, you have to give to everybody.... Together, the Progressive Democrats and Fianna Fáil have eighty seats in the Dáil and are requiring the votes of four Independents at every vote to help them through.... Expect promises of an extension of the DART to Newtonmount Kennedy and roads around the sugarloaf in a bid to keep her onside." 12

Indeed, there was so much anger within the Fianna Fáil Party that Bertie Ahern and Charles McCreevy called a meeting with the parliamentary party at Leinster House on November 19th 1999 at which 40 members attended. They denied that Jackie Healy-Rae had swayed their decision and noted that the idea had been mooted in Department of Finance discussions in July. The politics of turf threatened to dominate once more then, with support for the coalition rather than party allegiance being placed under threat on this occasion.

A second controversial point arising from the press release was that while the government made explicit that it had decided that a revised regional structure was needed, it was clear that it had no vision of what this structure might entail, nor had made any plans to implement changes in the near future. Despite an exhaustive debate on the issue, for some, the government still had failed to realise the urgency of creating new regional bodies for the success of the venture:

"Commissioner Monika Wulf-Mathies is on record as saying that there would need to be a greater involvement of local government in development activity than is currently the case before the Commission would agree to this kind of regionalisation. Otherwise it would seem, the Commission would regard the proposed regionalisation as 'subsidy shopping' and therefore totally unacceptable. The Minister for Finance apparently envisages 'light' regional structures whatever that may mean. On November 17th, the Taoiseach said in the Dáil that no legislation would be required to give effect to the proposed regionalisation, which leads me to conclude that he envisages no devolution of powers or influence over planning or expenditure. It remains to be seen what the Commission's reaction to that will be." (A. Dukes, T.D. for Kildare South, Fine Gael, Irish Times $20 / 11 / 98)^{13}$

In response to these criticisms, the Government issued a press release on February

12 Ireland Today, "Outfoxing the government the Wicklow way", 24/11/99.

13 Irish Times, "Government's ill prepared approach to regionalisation" 20/11/99. 
2nd 1999 providing more details of the planned new regional structures. ${ }^{14}$ Two new NUTS II regions were to be created; Border, Midlands, and West Regional Authority (including Kerry and Clare), and Southern and Eastern Regional Authority (Fig. 1). They were to have four roles; to promote the co-ordination of the provision of public services in their areas, to advise the government on the regional dimension of the National Development Plan; to monitor the general impact of all EU programmes of assistance under the CSF in their areas, and to manage new regional programmes in the next CSF. This last aspect was particularly interesting for it suggested that, for the first time, there would be some formal regional programming in the National Development Plan. Membership of the new regional authorities was to be drawn from elected representatives from the eight existing NUTS III regional authorities. These authorities were to remain and maintain their functions. The press release concluded that:

"The new structures at regional level will significantly increase the influence of regional authorities in the development of the National Development Plan. It also represents a significant devolution of responsibility to regional authorities... The Government are now hopeful of an early response from Eurostat on its application." 15

Despite being an improvement on what had existed before, the proposals remained vague. There was no guidance as to whether NUTS II regional authorities were to hold budgets and have power to decide expenditure. There was no indication of the amounts of money to be spent on regional programmes. There were no details of likely staffing levels. The relationships which would exist between NUTS II and NUTS III regional authorities were not adequately specified. For many, therefore, the advanced proposals represented nothing more than a cosmetic exercise, an attempt to convince Eurostat that Ireland was addressing concerns while avoiding specific commitments to empower the regions. Crucially, the official establishment of NUTS II authorities was to occur under a Ministerial Order, rather than through primary legislation. This was taken as proof that the government had no intention of getting involved in a debate which would force them into genuine devolution.

\section{Alleged political corruption: the Flynn affair}

At this point, it is important to insert into the narrative a strand that proved influential in shaping the context within which decisions about Ireland's application to Eurostat were taken. Political corruption and sleaze have haunted the Fianna Fáil Party since the 1980s and the reign of "The Boss", former Taoiseach Charles Haughey (Collins \& O’Raghallaigh, 1985; Sherriff, O’Brien, Punch \& Cannon, 1998). Indeed the Progressive Democrats, the coalition party sustaining the govern-

\footnotetext{
14 Press release, Taoiseach's Office, "New regional structures for regionalisation”, 2/2/99.

15 ibid.
} 
ment (Table 2), had been established precisely because some Fianna Fáil members had felt unable to continue in that Party. Across the period of 1997/1999, in particular however, and crucially in the midst of EU negotiations, the stability of the government was put under considerable strain by virtue of the rise of a whole series of new corruption charges. Of particular significance was the Flood Tribunal, the latest in a line of investigations into alleged payments made to politicians for planning favours.

In September 1998, Tom Gilmartin, a property developer, alleged that a donation of IR£50,000 he had made to the Fianna Fáil Party in the late 1980s had been personally appropriated by Padraig Flynn, a former Fianna Fáil Minister and then Ireland's sole EU Commissioner. Gilmartin claimed that he had been harassed by Flynn who was extremely worried about what the allegations might do to his chances of being re-nominated as Irish Commissioner. Faced with the allegation of political sleaze Bertie Ahern, it was suggested, was already recognising the impossibility of re-nominating Flynn. In early February 1999, Fine Gael tabled a Private Members' Motion in the Dáil asking for immediate clarification of the allegations from Flynn and recommending that if this was not forthcoming Flynn should be sacked as Commissioner.

On February 10th 1999, the Dáil debated a motion on Flynn's position. In an impressive speech T.D. Desmond O'Malley, a co-founder of the Progressive Democrats, argued:

"the questions being posed for Mr Flynn are not complicated; they are simple, straightforward, and easy to answer. And yet he declines to do so... Is he hoping that he will have been able to complete his term in Brussels before he is called to give evidence in Dublin Castle? Why else would he refuse to explain himself? What else does he have to fear from telling the truth... The public are interested to see revealed what the politicians of the 1980s got up to. But they are also interested to see how those revelations will be dealt with by the politicians of the 1990s." 16

The motion resulted in a call by the government for a full and immediate response to the allegations from Flynn. On March 2nd 1999, Ahern read a one page fax to the Dáil from Flynn indicating that his legal advisers had suggested that he should not respond to the Dáil motion and instead keep his evidence for the Flood Tribunal. This was to trigger further exchanges between the Dáil and Flynn, but without progress.

On Tuesday March 16th 1999, the affair was brought to an end in the most unexpected of circumstances. Following months of controversy, the EU Parliament forced the 20-strong EU Commissioners to resign. The Parliament had refused to sign off accounts for 1996 expenditure due to a raft of financial irregularities. While Flynn

\footnotetext{
${ }^{16}$ The Irish Times, "Speech of Desmond O’Malley T.D. for Limerick East in Dáil Éireann on Private
} Members' Motion to force Padraig Flynn to make a public statement on allegations of fraud" 12/2/99. 
was not directly involved in charges of corruption among EU Commissioners, the decision to resign en masse offered him the opportunity of a graceful exit. He would not be re-appointed but would remain with the other Commissioners in a caretaker capacity until September 1999.

The impact of the whole affair on the outcome of Ireland's negotiations over Agenda 2000 is impossible to establish. It did, nevertheless, mediate negotiations in at least two ways. First, the erosion of the relationship between Flynn and the Fianna Fáil Party must have undermined the effectiveness with which Ireland was able to lobby. On March 10th 1999 in a debate in the Dáil, Ahern was asked explicitly whether his relationship with Flynn was becoming detrimental to the Irish case. He indicated that he had met with Flynn only once since Christmas 1998 but defended his position by saying, "I do not need to talk to the Commissioner to obtain his insights and information". Other commentators were less convinced. The Irish Times on February 5th 1999, for instance, carried an article titled; "Bad time for a public dispute with Flynn". It continued:

"this is an exceptionally bad time to have such a bitter and public row between the government and the Irish member of the European Commission, Mr Padraig Flynn. Whilst Commissioners are not constitutionally representatives of the member states, everyone knows they play an essential role in mediating and communicating between Brussels and national capitals." 17

Second, on February 26th 1999, and in part as a consequence of public perception of the affair, The Irish Times published a poll showing that despite a buoyant economy, support for Fianna Fáil had dropped $8 \%$ points to $48 \%$ in four months, with the Taoiseach's personal rating falling from $81 \%$ to $70 \% .^{18}$ The poll also suggested that $51 \%$ of voters wanted an election if allegations could be proven. The already weak coalition government was on the verge of collapse. The consequence was that it became even more important for Fianna Fáil to keep Independent T.D.s like Jackie Healy Rae on side. They had to persist with their inclusion of Clare and Kerry in the application to Eurostat. Furthermore, the government came under more pressure to resolve the Agenda 2000 negotiations satisfactorily to prove that their handling of the Flynn affair was not to the detriment of Ireland.

\section{Negotiation and compromise with the EU Commission}

On February 24th 1999, Eurostat formally rejected Ireland's application to create two NUTS II regions. The rejection, it was argued, was based firstly upon Eurostat's belief that the addition of Kerry and Clare represented a cobbled together effort to maximise EU transfers, and secondly, the failure of Ireland to erect new regional

17 The Irish Times, "Bad time for public dispute with Flynn", 5/2/99.

${ }^{18}$ The Irish Times, "FF support drops 8 points in four months", 26/2/99. 
structures which reflected genuine devolution. Amidst an avalanche of criticisms, led by Fine Gael and the Labour Party, The Irish Times on March 1st reported:

"Not unexpectedly, the Government's clumsy and ill-conceived exercise in supposed 'regionalisation' has hit the buffers in Brussels. Eurostat,... is not convinced that counties Clare and Kerry should be eligible for the maximum level of EU funding. Critically, Eurostat is also sceptical about the government's commitment to fully-fledged regional power... Eurostat sees the regional structures for what they are: a token effort inspired centrally by the need to optimise receipts from EU Structural Funds.... In truth, the government has only itself to blame. For a decade and more the Commission has championed an approach whereby the allocation and distribution of EU Structural Funds is channelled through proper regional structures.... The government has responded to this with a minimalist approach to regionalisation drawn up by the Department of Finance, which yields little substantial powers to the regions." 19

This kind of thinking was to become central to the debates which followed. In reality, Eurostat is confined in its decision making to statistical criteria only and the decision over splitting the country in two ought to have come down simply to the capacity of the proposed area to meet EU guidelines for Objective 1 status. The drive for regional governance is championed by the Commission who ought to have had no influence on the decision making process. What marked out the Irish analysis however, was a suspicion that the Commission had shaped Eurostat's decision because of the failure of Ireland to give due credit to devolution in particular. Whether this kind of thinking had any basis in reality is largely irrelevant. Opposition parties jumped on suspicions and critique was constructed on the basis that Eurostat had judged the case on political grounds.

In a debate in the Dáil on March 3rd 1999, some valuable insights can be obtained regarding the government's commitment to regional devolution. Despite the earlier promise, no Ministerial Order had yet been signed to set up the two new NUTS II authorities. Minister for Local Government Noel Dempsey was relentlessly goaded by Labour and Fine Gael as to why the new regions had not been established. It was clear that if Eurostat could not be convinced to change its decision, the new authorities might not be set up at all. They had to be understood therefore, as being nothing more than an exercise in political opportunism:

ND - It was made clear at the time that consultations were ongoing with Eurostat and the European Commission and that once final details were agreed, the two regions would be established.

19 The Irish Times, "Regional policy in flitters", 1/3/99. 
EG - This is news. I understood on 10th February, when the government announced the establishment of two new so-called group regions, that this decision had been arrived at by government following a lengthy period of deliberation since last July, was independent of anything happening in Eurostat, and was based on the regional needs of the country.... May I take it that the two regions will be established not on the basis of national policy but on the basis of what Eurostat and the European Commission tell the Government... Who is running this country?

ND - We are...

EG - Eurostat.... There is no other country which would allow regions to be set up by Eurostat.

(N. Dempsey (ND), T.D. for Meath, Minister for the Environment and Local Government, Fianna Fáil, and E. Gilmore (EG), T.D. for Dún Laoghaire, Labour: Dáil Debates, 1/3/99)

The Government reacted angrily to the Eurostat decision, and even though surprised by the bluntness of the response, indicated that the battle was not over. It remained committed to the original application and Bertie Ahern arranged to meet Jacques Santer on the matter, Charles McCreevy wrote a letter of protest to the Economic Affairs Commissioner, Mr Yves Thibault de Silguy, and high level officials in the Dublin Government arranged a top level meeting with Eurostat officials. Commenting upon these gestures, The Irish Times of March 1st reported: "For all this brave talk there is a definite sense that the government has burnt its bridges in Brussels... and is engaged in a rearguard action". ${ }^{20}$ Going into the final phase of discussions on Agenda 2000 therefore, the Irish government had to revise its thinking and devise a strategy for the final assault.

The chief stance taken was to empathise with those countries (particularly Germany) who were concerned with contributions, but to seek as much of what assistance was available. Ireland was accepting that it would suffer shortfalls but was looking for a "soft landing". In press coverage, Ahern publicly declared that he was seeking a deal of around 4 billion ECU. Among the most critical aspects of his "bottom line" were:

"a recognition that Ireland's recent economic growth had occurred only since 1993, that there was, therefore, a need to look beyond the figures to recognise the serious infrastructural problems which remained, and the need for continued

\footnotetext{
20 ibid.
} 
help to consolidate growth. At a minimum, Ireland needed: acceptance of the partition of the country into Objective 1 and Objective 1 in transition regions; adequate transition arrangements in the transition region, and continued eligibility for the Cohesion Fund."21

Ireland's movement towards a negotiated compromise was met by a reciprocal movement by the German government. Chancellor Gerard Schroeder faced a number of pressures which encouraged a softening of the German position, and given their Presidency of the EU, this encouraged a similar approach from most net contributors. Schroeder was operating a week after the resignation of his Finance Minister Oscar Lafontaine and one month after the entire Commission resigned for corruption, and fearing what a botched summit might do for further devaluation of the already fragile and tumbling new Euro currency, had a mind to broker a compromise. Shifts in the German position were beginning to generate optimism in Ireland that the new context might encourage Eurostat to accept at least a version of the regionalisation strategy.

The Irish Times of March 21st 1999 announced that Eurostat had provisionally agreed to a modified regionalisation proposal, which excluded Clare and Kerry, ahead of the final summit scheduled for Berlin on March 24-26th. Then, in an article extolling the virtues of the Irish government, on March 22nd, Ireland Today confirmed:

"The good news is that it now looks very positive that the EU will grant Objective 1 status to 13 counties in Ireland... The bad news is that the counties of Kerry and Clare will not be included.... People who understand how negotiations work are saying that the Irish government has, once again, out-foxed the EU... Taoiseach Bertie Ahern knows how negotiations work. He knew there was little point of putting forward 13 counties for Objective 1 status. Where could you negotiate from that position? Ahern saw an opportunity to develop a negotiation position that would solve several problems. By including two extra counties, he was able to bring Independent Deputy Jackie Healy-Rae of Kerry firmly onto the government's side, whilst giving him room to compromise with the EU... The Irish government has retained, against all odds, Objective 1 status for 13 counties.... This could go down as a 'masterstroke' in EU negotiations." 22

Instead of being arrogant and complacent and mishandling the original application, the government, it appeared, had got it right after all. The coalition was strengthened going into the Berlin negotiations. On Friday March 26 after gruelling negotiations at Berlin, agreement was reached by all European governments regarding the final accommodation which was to endure between 2000 and 2006. Reporting back to the Dáil on April 1st 1999, Finance Minister Charles McCreevy was in self congratulat-

\footnotetext{
${ }^{21}$ Press release, Taoiseach's Office, "Statement by the Taoiseach Mr Bertie Ahern T.D. in advance of the opening of the negotiations on Agenda 2000", 21/2/99.

22 Ireland Today, "Success or failure", 22/3/99.
} 
ory mood. McCreevy pointed to four major results of the Berlin negotiations which bore direct relevance to Ireland:

1. EU transfers to Ireland across the period 2000-2006 would amount to 12.7 billion Euro.

2. Ireland would continue to retain entitlement to Cohesion Funds subject to a midterm review in 2003.

3. Ireland's total share of Structural Funds would be around 4.25 billion Euro.

4. Finally, and of greatest significance in the present context, the regionalisation proposal would be accepted (subject to the exclusion of Clare and Kerry) and net Ireland an additional 590 million Euro.

In other words, against expectations and events conspiring against the government, Ireland could take satisfaction from doing well in the Berlin negotiations. It had succeeded in securing a reasonable outcome (compare with the projections of Brennan (1998), for instance), a modified version of the regionalisation strategy had been accepted, and it would get the "soft landing" it desired. Ireland would still emerge as one of the biggest losers in the new programming period but losses would not be as great as perhaps initially feared.

\section{Conclusion: a reading of Ireland's experience}

Until 1998, Europe's insistence upon a role for regional and local actors clearly had little impact upon Ireland's institutional apparatus, despite the fact the country was drawing down substantial Structural Funds. A combination of the new context created by Agenda 2000 and the accelerated progress of the Irish economy from 1993, however, evidently afforded the EU Commission a new opportunity to force the Irish state into a reconsideration of the role of regional actors. The Irish government was dedicated towards maximising intake from EU transfers. Given the state's history of over centralisation and the key role played by the Department of Finance in previous rounds of Structural Funds, however, it lacked an appetite for the kinds of devolution demanded by the Commission. Its own proposals, whilst furnishing regions with greater responsibility, clearly fell short of the European ideal.

The stalemate was to break in a compromise struck in the run-up to the Berlin summit. It seemed that Ireland had managed to face down the EU Commission. Whilst the Commission succeeded in ensuring that the two new NUTS II regions had nominal integrity, it failed to extract a detailed commitment to extended empowerment of regional actors. Against the backdrop of a legitimation crisis among EU Commissioners and a struggling Euro currency, Eurostat agreed in March 1999 to much the same regionalisation proposal it had rejected in February 1999. The tapestry of NUTS III regional authorities had been successfully deployed as part of an exercise in subsidy shopping

In ending this paper, it is worthwhile reflecting upon three issues which would appear to have wider significance to other case studies of the role of Euro-regionalism 
in the re-scaling of regional governance in member states. First, it is clear that the existing scale division of the Irish state rendered regional and local actors so impotent that they lacked the capacity to wrestle power from Dublin. Regional armatures in Ireland were animated by the circumstances in which the Irish state found itself but their historical weakness militated against their capacity to make a difference to the evolution and outcome of debates. Indeed so weak is regional governance in Ireland that its aspirations have been limited towards encouraging the state to move away from national/sectoral and towards spatial/regional planning. At no stage were the concepts of regional suffrage and a substantial devolution of decision making powers seriously countenanced even by regions themselves.

In an effort to explain the limited ambitions of regional actors, it is useful to revisit a number of concepts introduced above. In part, the relatively limited capacity of regions to make a difference can be traced to the scale dependency of regional actors. Rooted in the fortunes of the national economy, regional actors lack the kinds of regional dependencies which, if shared by other non-state actors, might have succeeded in stimulating them to embark upon more vociferous and ambitious politicking. This said, the dependency of sub-national actors on the central state might in turn have been expected to create an interest in using EU funds to liberate the regions from Dublin. MacLeod (1999), for example, has shown how regional actors in Scotland have approached Euro-regionalism as a new "space of engagement" (Cox, 1998b). Here, the jumping of scales creates a new kind of dependency which can offer more security. It is clear that so weak are regional actors in Ireland that they have lacked the resources and organisational capacity to think of Europe at this stage as a new "space of engagement".

The limited success of regions in capitalising on the context created by Agenda 2000, however, requires an explanation which surpasses the scale dependencies of state and non-state actors. It has perhaps been the lack of a regional imaginary to underpin the regionalisation strategy that has been its greatest downfall. Out of convenience and as part of an exercise in subsidy shopping, Ireland attempted to manufacture two regions from an existing regional structure which lacked cultural integrity in the first instance. The BMW region represents little more than a "named" economic space which makes sense only in terms of the rules of the game established by Europe. Its discursive construction failed to stimulate any popular sense of loyalty in a country that is already bereft of meaningful regional identities. It has been this lack of a representational trope of the "region" that has undermined the possibility of animating social blocs at the regional level. Reflecting upon the debates over Agenda 2000 Liam Scollan, Chief Executive of the Western Development Commission, observed:

"the scale of governance which we truly want at regional level will only be determined when we have managed to discuss and understand fully the broader distinctive character of different regions and the extent to which such a character can be sustained and developed by more or less regional governance. Perhaps there will always be poverty in our regional development policies unless they are 
built from strong social and cultural as well as economic foundations in the regions." 23

Second, the tendencies for local interests to work through T.D.s in Ireland and, therefore, to become de-localised, manifested itself in debates. In achieving national agreement to pursue regionalisation, the Irish state had to act to ward off the threat of a turf war that cut across party allegiance. The pursuit of regionalisation was at the expense of commitments to T.D.s and Senators in Objective 1 in transition areas, and particularly in the urban "blackspots", that domestic resources would be allocated to their locales to offset EU losses. A strong cross-party, territorial based alliance managed to extract these commitments at the height of the "summer of discontent". The next National Development Plan therefore will need to start from the basis of evening up imbalances created by EU transfers, irrespective of the EU's principle of "additionality" (Fitzpatrick Associates Economic Consultants, 1999a,b).

It would be misleading, however, to argue that turf politics overshadowed party allegiance. It is questionable whether party allegiance was ever diluted to this extent. Where the politics of space did emerge triumphant was in the context of the capacity of an Independent T.D. to extract "favours" as a condition for his support of the regionalisation strategy and the weak coalition government more generally. Exploiting the fragility of the government, Independent T.D. Jackie Healy-Rae flexed his muscles and forced the government to put the entire regionalisation proposal at risk by including Clare and Kerry in the original application for Objective 1 status. With its history of weak coalition governments, Ireland more so than other states, would seem to be particularly vulnerable to this kind of triumph of spatial over sectoral politics, constituency over party.

Finally, it is hoped that the narrative outlined above impresses the need to embrace research methods which not only furnish insights into the messiness that surrounds struggles over scales of governance, but also draws attention to the importance of allowing for the contingent and conjunctural in analysis. In the above case study for instance, the role of allegations of political corruption by Irish Commissioner Padraig Flynn cannot be ignored. Not only did it further weaken the government but it threatened to undermine the skill with which Ireland could negotiate a compromise. Moreover, the launching of the Euro and its poor performance allied with the mass resignation of EU Commissioners played a crucial role in the compromise that was finally brokered. Central to the process based approach therefore, must be a recognition that from time to time contextual and happenstance events will surface and play a significant role in the mediation of Euro-regionalism.

Writing about the influence of Structural Fund transfers to Ireland in the period 1987 to 1996, Brigid Laffan has argued that while not responsible for institutional changes of consequence, "EU monies have disturbed territorial politics in Ireland" [Italics added] (Laffan, 1996: 320). The evidence presented in this paper suggests

\footnotetext{
${ }^{23}$ Liam Scollan, Chief Executive of the Western Development Commission, personal communication, 25/11/99.
} 
that the Euro-regionalism project has been considerably more disturbing for the Irish government since 1996. Euro-regionalism forced the government into a highly public debate about the future status to be accorded to regional authorities. It is perhaps a sad testimony, nevertheless, that even in the midst of extraordinary levels of pressure, the scale division of labour within the Irish state remains overwhelmingly centralist, with only a marginal strengthening of the existing base of regional governance. The EU Commission, it seems, lacked the political will to fully capitalise upon the temporary shift in the balance of power in its favour.

\section{Acknowledgements}

The author would like to thank the Royal Geographical Society (with the Institute of British Geographers) for financial assistance received through the HSBC Small Grants Scheme which allowed interviews to be conducted in Ireland. Special thanks go to Ronan Paddison and Dr Peter Shirlow for initial support for the project. The perceptive and helpful comments from three anonymous referees and David Slater on an earlier version of the paper are also gratefully acknowledged. Finally, thanks go to Lorraine Nelson and George Yule for cartographic assistance.

\section{References}

Andrews, C. (1998). EU enlargement: the political process. House of Commons research papers, 98/55. London: HMSO.

Bachtler, J., \& Turok, I. (1997). The coherence of EU regional policy: contrasting perspectives on the structural funds. London: Jessica Kingsley.

Bachtler, J. (1998). Reforming the Structural Funds: Challenges for EU regional policy. European Planning Studies, 6, 645-664.

Baeten, G., Swyngedouw, E., \& Albrechts, L. (1999). Politics, institutions and regional restructuring processes: from managed growth to planned fragmentation in the reconversion of Belgium's last coal mining region. Regional Studies, 33, 247-258.

Benz, A., \& Eberlein, B. (1999). The Europeanisation of regional policies: patterns of multi-level governance. Journal of European Public Policy, 6, 329-348.

Border Regional Authority (1998a). The Border Region after 1999: the case for special status. Cavan: Border Regional Authority.

Border Regional Authority (1998b). The submission from the Border Regional Authority regarding Structural and Cohesion Fund Assisted operations 2000-2006. Cavan: Border Regional Authority.

Brennan, P. (1998). Agenda 2000: implications for Ireland. Dublin: IBEC.

Brenner, N. (1998). Between fixity and motion: accumulation, territorial organisation, and the historical geography of spatial scales. Environment and Planning D: Society and Space, 16, 459-481.

Brenner, N. (1999). Globalisation as re-territorialisation: The re-scaling of urban governance in the European Union. Urban Studies, 36, 431-451.

Callanan, B. (1999). Leaders, visions and networks - Ireland's Shannon story: a case study of local and regional development. Dublin: Irish Academic Press.

Collins, N., \& O'Raghallaigh, C. (1985). Political sleaze in the Republic of Ireland. Parliamentary Affairs, 48, 697-710.

CEC (1997a). Agenda 2000 Volume 1: for a stronger and wider Union. Brussels: CEC.

CEC (1997b). Agenda 2000 Volume 2: Reinforcing the pre-accession strategy. Brussels: CEC. 
Cox, K. R. (1998a). Spaces of dependence, spaces of engagement and the politics of scale, or: looking for local politics. Political Geography, 17, 1-23.

Cox, K. R. (1998b). The American politics of local economic development: from locality to center and back again. (Unpublished paper, available from the author).

Cox, K. R., \& Mair, A. (1988). Locality and community in the politics of local economic development. Annals of the Association of American Geographers, 78, 307-325.

Coyle, C., \& Sinnott, R. (1992). Regional elites, regional "powerlessness", and European regional policy in Ireland. Regional Politics and Policy, 2, 71-108.

Delaney, D., \& Leitner, H. (1997). The political construction of scale. Political Geography, 16, 93-97.

Fitzpatrick Associates Economic Consultants (1999a). Border Midlands and Western NUTS II region: development strategy 2000-2006. Dublin: Fitzpatrick Associates Economic Consultants.

Fitzpatrick Associates Economic Consultants (1999b). Southern and Eastern NUTS II region: development strategy 2000-2006. Dublin: Fitzpatrick Associates Economic Consultants.

Hooghe, L. (1996). Building a Europe with the regions: the changing role of the European Commission. In L. Hooghe, Cohesion Policy and European integration: building multi-level governance (pp. 89126). Oxford: Oxford University Press.

Keating, M., \& Loughlin, J. (1996). The political economy of regionalism. London: Frank Cass.

Laffan, B. (1996). Ireland: A region without regions - The odd man out. In L. Hooghe, Cohesion Policy and European integration: building multi-level governance (pp. 320-337). Oxford: Oxford University Press.

Laffan, B. (1999). Ireland in the European Union: the regional brochure. Brussels: European Union.

Laffan, B., \& O'Donnell, R. (1998). Ireland and the growth of international governance. In W. Crotty, \& D. E. Schmitt, Ireland and the politics of change (pp. 156-176). London: Longman.

Laver, M. (1998). Party policy in Ireland 1997: results from an expert survey. Irish Political Studies, 13, $159-171$.

Le Gales, P. (1998). Conclusion — government and governance of regions: structural weaknesses and new mobilisations. In P. Le Gales, \& C. Lequesne, Regions in Europe (pp. 239-267). London: Routledge.

McAleese, D., \& Mathews, A. (1987). The Single European Act and Ireland: Implications for a small member state. Journal of Common Market Studies, 26, 39-60.

McCafferty, D. \& Walsh, J. (1999). Local partnerships in local governance: the sub regional dimension of devolution. European Regional Studies Association 39th European Congress, Dublin 23-27th August 1999 (copies of paper from available from the author).

MacLeod, G., \& Goodwin, M. (1999). Reconstructing an urban and regional political economy: on the state, politics, scale and explanation. Political Geography, 18, 697-730.

MacLeod, G. (1999). Place, politics, and scale dependence: exploring the structuration of EuroRegionalism. European Urban and Regional Studies, 6, 231-253.

Marks, G. (1996). Exploring and explaining variation in EU cohesion policy. In L. Hooghe, Cohesion Policy and European integration: building multi-level governance (pp. 396-422). Oxford: Oxford University Press.

Michie, R., \& Fitzgerald, R. (1997). The evolution of the Structural Funds. In J. Bachtler, \& I. Turok, The coherence of EU regional policy: contrasting perspectives on the structural funds (pp. 14-28). London: Jessica Kingsley.

Midland Regional Authority (1998). Submission for Structural and Cohesion funds for the period 20002006. Tullamore: Midland Regional Authority.

Murray, M. R., Greer, J. V., \& Walsh, J. A. (1995). Economic restructuring within the European periphery, the case of Ireland. In S. Hardy, M. Hart, L. Albrechts, \& A. Katos, An enlarged Europe: regions in competition? (pp. 295-312). London: Jessica Kingsley.

Nanetti, R. Y. (1996). EU cohesion and territorial restructuring in the member states. In L. Hooghe, Cohesion Policy and European integration: building multi-level governance (pp. 59-88). Oxford: Oxford University Press.

O’Donnell, R., \& Walsh, J. (1995). Ireland, region and state in the European Union. In M. Rhodes, The regions and the new Europe: patterns in core and periphery development (pp. 200-228). Manchester: Manchester University Press. 
O’Leary, E. (1997). The convergence of performance of Ireland among EU countries, 1960-90. Journal of Economic Studies, 24, 43-58.

O’Leary, J. (1998). Irish economic development: some regional perspectives. Irish Times, 7/12/98.

O'Leary, J. (1999). Regional income estimates for Ireland 1995. Regional Studies, 33, 805-815.

Peillon, M. (1994). Placing Ireland in a comparative perspective. The Economic and Social review, 25, 179-195.

Rhodes, M. (1995). The regions and the new Europe: patterns in core and periphery development. Manchester: Manchester University Press.

Sherriff, A. M., O’Brien, G., Punch, E., \& Cannon, M. (1998). The Dunnes payment scandal, Charles Haughey and contemporary Irish political culture. Crime, Law and Social Change, 30, 43-65.

Sinnott, R. (1986). Party differences and spatial representations: The Irish case. British Journal of Political Science, 16, 217-241.

Swyengedouw, E. (1997). Neither global nor local, "glocalisation" and the politics of scale. In K. Cox, Spaces of globalisation: reasserting the power of the local (pp. 138-166). New York: Guilford.

Walsh, J. A. (1995). EC Structural Funds and economic development in the Republic of Ireland. In P. Shirlow, Development Ireland: contemporary issues (pp. 54-68). London: Pluto Press.

West Regional Authority (1998). West Regional Development Plan: Structural and Cohesion funds 20002006. Galway: West Regional Authority.

Western Development Commission (1999). Blueprint for success: a development plan for the west 2000_ 2006. Ballaghadereen: Western Development Commission. 